\section{Daniel Avelino}

Debora Diniz

\section{International perspective on embryonic stem cell research}

\begin{abstract}
OBJECTIVE: To comparatively analyze governmental regulations on embryonic stem cell research among countries.
\end{abstract}

METHODS: The study was performed between March and May 2008, using a direct electronic search through official databases of legislative documents from 25 selected countries, confirmed by email consultation with researchers and authorities from these countries, when necessary.

RESULTS: Results showed a trend to allow the practice of embryonic stem cell research, though with strict ethical restrictions. Among the countries analyzed, only Italy and Germany explicitly condemned the extraction of stem cells and only Italy prohibits their subsequent use. Recent judicial decisions in Brazil are in accordance with the international regulatory context of embryo research.

CONCLUSIONS: The trend observed represents freedom of research to promote knowledge as a public good, emphasized by the expectation of therapeutic potentiality of embryonic stem cell research to treat and cure diseases without any medical care.

DESCRIPTORS: Embryonic Stem Cells. Embryo Research, legislation \& jurisprudence. Legislation Science and Technology. Legislation. Ethics, Research. Bioethics, trends.

\section{INTRODUCTION}

In Brazil, embryonic stem cell research was regulated by Law $n^{\circ} 11,105$, from March $24^{\text {th }}, 2005$, known as the Biosafety Law. ${ }^{\text {a }}$ Article 5 of this law allows manipulation of human embryos, produced by in vitro fertilization, to collect stem cells, though with restrictions. Subsequently, Decree $n^{\circ} 5,591$, from November $22^{\text {nd }}, 2005$, defined as "non-viable embryos" those with proven genetic alterations that prevent development due to lack of cleavage. ${ }^{b}$ This means that the Brazilian law authorized research, preferably in embryos that will not be used for reproductive purposes after diagnostic procedures.

In May 2005, the Brazilian Attorney General filed the Ação Direta de Inconstitucionalidade 3,510 (ADIn 3,510 - Direct Action of Unconstitutionality),

Anis Instituto de Bioética, Direitos Humanos e Gênero. Brasília, DF, Brasil

\section{Correspondence:}

Daniel Avelino

Anis Instituto de Bioética, Direitos Humanos e Gênero

Caixa Postal 8011

70673-970 Brasília, DF, Brasil

E-mail: davelino@ig.com.br a Brasil. Lei no 11.105, de 24 de março de 2005. Regulamenta os incisos II, IV e V do § 1o do art. 225 da Constituição Federal, estabelece normas de segurança e mecanismos de fiscalização de atividades que envolvam organismos geneticamente modificados - OGM e seus derivados, cria o Conselho Nacional de Biossegurança - CNBS, reestrutura a Comissão Técnica Nacional de Biossegurança - CTNBio, dispõe sobre a Política Nacional de Biossegurança - PNB, revoga a Lei no 8.974, de 5 de janeiro de 1995, e a Medida Provisória no 2.191-9, de 23 de agosto de 2001, e os arts. 5o, 6o, 7o, 8o, 9o, 10 e 16 da Lei no 10.814, de 15 de dezembro de 2003, e dá outras providências [internet]. [cited 2008 May 24]. Available from: http://www.planalto.gov.br/ ccivil_03/_Ato2004-2006/2005/Lei/L11105.htm. 11.105, de 24 de março de 2005, que regulamenta os incisos II, IV e V do § 1o do art. 225 da Constituição Federal, e dá outras providências. [internet]. [cited 2008 May 24]. Available from: http://www.planalto.gov.br/ccivil_03/_Ato2004-2006/2005/Decreto/D5591.htm.
${ }^{b}$ Brasil. Decreto n 5.591, de 22 de novembro de 2005. Regulamenta dispositivos da Lei no 
defending the unconstitutionality of article 5, grounded on the central thesis that "human life occurs at and since the moment of conception". Taking this argument into consideration, actions that prevent cell development to form the fetus are understood as an aggression against life and the dignity of a human being. If this assumption is valid, the unconstitutionality of embryonic stem cell research is acknowledged, as it stops cell division and prevents embryonic development.

The ADIn required the Supremo Tribunal Federal (STF - Supreme Court) to make an official statement about the statute of the embryo with potentiality of life according to the Brazilian laws. During this process, the first public hearing in the history of the Supreme Court took place, with the participation of experts on this subject, after which the ADIn was ruled unfounded and the court confirmed the constitutionality of article 5 of Law $n^{\circ} 11,105 / 2005$. Despite the objection to the Lei de Biossegurança (Biosafety Law), the Ministry of Health invested R\$ 24 million in embryonic stem cell research in Brazil, especially in heart diseases and cell therapies. The first results were announced in October 2008, with the first Brazilian line produced by the University of São Paulo.,

The Supreme Court judgment, in addition to providing an extended revision of the constitutionality of human embryo research, showed significant results for other areas of public health in Brazil. The first area is abortion, with an ethical debate over the beginning of life and the judicial protections the human embryo and fetus should have. The second area is the ethical review of scientific research in the country, with the Sistema Comitês de Ética em Pesquisa/Comissão Nacional de Ética em Pesquisa (CEP/Conep - Research Ethics Committee/National Research Ethics Commission system). Some of the judges voted partially for the constitutionality of Law $n^{\circ} 11,105$, due to reservations concerning the monitoring system of scientific human embryo research.

The present study aimed to comparatively analyze governmental regulations on embryonic stem cell research among countries.

\section{METHODS}

The international comparative study on regulation of embryonic stem cell research was performed between March and May 2008 by the Anis Instituto de Bioética,
Direitos Humanos e Gênero (Anis: Institute of Bioethics, Human Rights and Gender), which participated in the judgment as amicus curiae. Data collection was conducted by an online search through official databases available in each country. ${ }^{\mathrm{d}}$ Data were compared to information provided by international institutions and non-governmental organizations to confirm their validity, relevance and effectiveness. The official versions of the legal texts were subsequently located and recorded, according to publication by governmental document registration institutions. Whenever possible and available, versions in their original language were gathered, while official translations were a secondary source. The final data collection stage consisted in confirming and validating information by contacting researchers and authorities from the countries involved.

To select and classify countries more accurately, only those that had (legal or infra-legal) norms established on this topic were considered, thus excluding from the sample those about which there were no specific legislative or administrative norms on embryonic stem cell research. This led the sample studied to comprise 25 countries: Canada, the Commonwealth of Australia, the Swiss Confederation, South Korea, the State of Israel, the United States, The United States of Mexico, the Russian Federation, Japan, the Kingdom of Denmark, the Kingdom of Spain, the Kingdom of Norway, the Kingdom of Sweden, the Kingdom of the Netherlands, the United Kingdom and Northern Ireland, the Republic of South Africa, the Republic of Finland, the Republic of France, the Republic of India, the Republic of Singapore, the Republic of Portugal, the German Democratic Republic, the Islamic Republic of Iran, the Italian Republic and the People's Republic of China.

These sample countries are democratic and secular in their majority, with technological, medical and scientific development comparable to or above the Brazilian one, and together comprise more than half of the world population. In addition, these countries are responsible for the majority of health publications in the main scientific journals and the most relevant international patent registrations. Finally, they also represent five world regions and include significant religious communities.

Once the information was gathered, countries were classified into three general categories, according to the level of embryonic research regulation:

\footnotetext{
a Procurador Geral da República. Ação Direta de Inconstitucionalidade n 3.510 [internet]. Brasília: Supremo Tribunal Federal; 2005. [cited 2008 May 24].Available from: http://www.stf.gov.br/portal/peticaolnicial/fazerDownload.asp?classe=ADI\&processo=3510.

b Temporão JG. Células-tronco e progresso da ciência [internet]. Blog do Noblat. 13 Fev 2008. [cited 2008 May 24]. Available from: http:// oglobo.globo.com/pais/noblat/post.asp?cod_post=90021

c Escobar H. Brasil desenvolve sua $1^{\text {a }}$ linhagem de célula-tronco embrionária [Internet]. São Paulo: Centro de Estudos do Genoma Humano, 2008. [cited 2008 May 24]. Available from: http://genoma.ib.usp.br/noticias/noticias_estadao081001.php

${ }^{\mathrm{d}}$ To refer to the map with the research results and to the list of the normative acts considered, please visit the online version of this article, available from Vol.43(3) www.scielo.br/rsp.
} 
1. Countries that allow embryonic research with imported lines exclusively. This includes cases where embryo research is allowed with imported lines exclusively, admitting manipulation of previously extracted stem cells, in accordance with strict ethical criteria, but with the prohibition of collection of new embryonic lines.

2. Countries that allow research with both national and imported lines. A wide variety of situations are involved, where embryo research is allowed by legal or administrative norms, or yet in accordance with biomedical and administrative procedures with varied levels of strictness. Considering cases where the legislation is not explicit concerning permission and research effectively occurs according to other norms, and in order to avoid eventual contradictions between the legal mark text and the practical research dimension in these countries, this category includes all situations in which research occurs based on an official statement of these countries' authorities, whether legislated or not.

3. Countries that do not allow embryo research under any circumstances, according to their current laws.

\section{ANALYSIS AND DISCUSSION OF RESULTS}

\section{Comparative international perspective}

Results showed that the international tendency is towards recognizing the ethical legitimacy of scientific embryonic stem cell research (Table). ${ }^{\mathrm{a}}$

The first international regulations date back to the 1990s, a period of reproductive technology dissemination to confront infertility and stem cell research issues. The case of the United Kingdom and Northern Ireland is a paradigm, as it represents a phenomenon that repeated itself in different countries in the last decade: research regulation was triggered by a broad bioethical debate on reproductive technology. The Warnock Report was a pioneering ethical document, where the concept of preembryo was proposed to represent the human cells on the first 14 days of development. ${ }^{15}$ As a result of almost a decade of ethical debate, the United Kingdom was the first country to authorize embryonic stem cell research and therapeutic cloning by law, in $2001 .^{3}$

Law $n^{\circ} 11,105 / 2005$ mentions frozen embryos and non-viable embryos, even though Resolution $n^{\circ} 33$ by the Board of Directors of the Agência Nacional de Vigilância Sanitária (Anvisa - National Health Surveillance Agency), from February $17^{\text {th }} 2006$, uses the concept "pre-embryo", as proposed by the Warnock Report (1984, p.18): "product of fusion of germinating cells up to 14 days after in vivo or in vitro fertilization, when the structure that will subsequently become the nervous system begins to form". ${ }^{15}$ In this sense, the Brazilian legal and regulatory framework adopts a double terminology to represent human cells on the first 14 days of conception, i.e. "embryo" and "pre-embryo", which, to a certain extent, reflects the conceptual diversity of the international debate. ${ }^{\mathrm{b}}$

Many countries authorize research with frozen embryos remaining from assisted reproduction clinics exclusively, as proposed by the Brazilian law. Remaining embryos are those left out by a couple's reproduction project, who sought medicine to have biologically related children. As a general rule, after the reproduction project fulfills its purpose, couples prefer to donate frozen embryos to scientific research rather than discard them. ${ }^{1,2,9,10}$ This is the legislative situation in Brazil, the Republic of France, and the Kingdom of the Netherlands, for example. The Kingdom of Norway authorizes research with embryos remaining from assisted reproduction clinics, even though it had maintained its prohibition until January 2008, when Law $n^{\circ} 31$, from June $15^{\text {th }}, 2007$, came into force and the restriction was abolished. Other countries, however, in addition to allowing research with remaining embryos, authorize the production of embryos for scientific investigation purposes exclusively, as is the case of the Commonwealth of Australia, Japan, the Republic of South Africa, the Republic of Singapore, the People's Republic of China and the Kingdom of Sweden.

The following countries authorize research with embryonic stem cells by law, similarly to Brazil: the Kingdom of Denmark, the Kingdom of Spain, the Republic of Finland, the Republic of France, United Kingdom and the Kingdom of Sweden. Other countries allow research to be performed without a conclusive legislative debate, as occurred in the Republic of India and the People's Republic of China. In such countries, an official statement from the national bioethics consulting commission or ministry of health was adopted. Moreover, there are countries that authorize research with existing embryonic lines and previously frozen embryos, while the legislative debate unfolds locally, as is the case of the Islamic Republic of Iran.

The United States are a country of reference in the international debate on bioethics, even though their national legal framework is restricted to issues associated with research funding. Embryonic stem cell research is authorized in the US, provided it is not subsidized by federal funds. The 2001 legislation allows research with previously existing stem cell lines to be funded by federal

\footnotetext{
${ }^{a}$ To refer to the map with the research results and to the list of the normative acts considered, please visit the online version of this article, available from Vol.43(3) www.scielo.br/rsp.

${ }^{b}$ Agência Nacional de Vigilância Sanitária. Resolução n 33, de 17 de fevereiro de 2006 [internet]. 2006. [cited 2008 May 24]. Available from: http://e-legis.anvisa.gov.br/leisref/public/showAct.php?id=20954\&word=\#'
} 
Table. Classification of countries analyzed, according to their regulation on embryonic stem cell research.

\begin{tabular}{lll}
\hline $\begin{array}{l}\text { 1. Countries that allow embryonic stem cell } \\
\text { research with imported lines exclusively }\end{array}$ & $\begin{array}{l}\text { 2. Countries that allow research with both } \\
\text { national and imported lines }\end{array}$ & $\begin{array}{l}\text { 3. Countries that do not allow } \\
\text { embryonic stem cell research }\end{array}$ \\
\hline & Canada & Commonwealth of Australia \\
& Swiss Confederation \\
& South Korea \\
& State of Israel \\
& The United States \\
& The United States of Mexico \\
& Russian Federation \\
& Japan \\
& Kingdom of Denmark \\
& Kingdom of Spain \\
& Kingdom of Norway \\
& Kingdom of Sweden \\
& Kingdom of the Netherlands \\
The United Kingdom and Northern Ireland & Italian Republic \\
& Republic of South Africa \\
& Republic of Finland \\
& Republic of France \\
& Republic of India \\
Republic of Singapore & Republic of Portugal \\
Islamic Republic of Iran & People's Republic of China \\
&
\end{tabular}

resources. Some states, such as California, Connecticut, Illinois and Maryland, passed laws authorizing state funding for embryonic stem cell research. Even with these public funding restrictions, international review articles indicate that the United States are the country that most publishes results of experimental research with embryonic stem cell lines, followed by the State of Israel, the United Kingdom and South Korea. ${ }^{6}$

The German Democratic Republic is another country with particular regulations. ${ }^{8}$ Embryonic stem cell research was regulated by law in 2002, prohibiting the use of German embryos and allowing research with previously imported embryonic stem cell lines, produced by other countries until January of that year. In February 2008, after intense negotiation with German scientific communities, the deadline was extended to enable lines obtained until May 2007 to be used. The German Democratic Republic formally prohibits the production of embryonic stem cells, but authorizes research with imported biological material, or non-German human cells. This combination between a restrictive legal framework, concerning the use of German embryonic stem cells, and the possibility of importation of lines was the target of several international debates in the field of bioethics. ${ }^{8,14}$ There is a consensus that the history of Nazism causes a democratic and reasonable debate in the German Democratic Republic to be more difficult, hence the prohibition of native biological material use. However, it is also agreed that the legitimacy of the principle of research freedom is what allowed the guarantee of the right to scientific investigation with imported lines.

\section{Non-viable embryos: Brazil and the Republic of Portugal}

One particularity of the Brazilian Law n ${ }^{\circ} 11,105 / 2005$ was its determination that research must be preferably performed with non-viable embryos. None of the 25 countries analyzed establishes a legal difference between viable and non-viable frozen embryos for scientific research, except, with other terms, article 9 of the Portuguese Law 32/2006. The international tendency is to make a distinction between frozen embryos from remaining reproduction projects and embryos produced for exclusive scientific research purposes. In this way, there is more harmony to recognize the investigation of frozen embryos as legitimate, not authorizing their production for research exclusively. There are bioethicists who sustain that the difference between embryos remaining from reproductive clinics and embryos produced for reproductive purposes must not be significant for the ethical assessment of the potential benefits provided by studies. ${ }^{4}$ Therefore, the differentiation between frozen embryos and non-viable embryos established by the Brazilian law does not exist in the majority of countries.

This singularity in the Brazilian law, regulated by Decree $\mathrm{n}^{\mathrm{o}} 5,591 / 2005$, which defined non-viable embryos, was already a discursive concession in favor of the metaphysics of the beginning of life, during the legislative negotiation. There is no threat to the right to life, of a non-viable frozen embryo from an assisted reproduction clinic. Even if women are forced to transfer non-viable frozen embryos to their wombs, none of them will become a 
fetus. In this sense, the debate over the beginning of life constitutes a false philosophical and scientific dilemma regarding the judgment of constitutionality of article 5 of Law $n^{\circ} 11,105 / 2005$, as previously stated.

The Republic of Portugal shows a unique situation concerning regulation in the context of the European Union. Up until Law n ${ }^{\circ} 32 / 2006$ about assisted reproduction was passed, the official statements of Life Sciences Ethics Councils acquired a regulating role in this country's scientific practice. The official opinion $\mathrm{n}^{\circ} 44$ about Medically Assisted Procreation stated that, if embryos remaining from in vitro fertilization were to be discarded, they could be used for scientific purposes. Law 32/2006 established rules for embryo research in the country and, in article 9 , restricted the possibilities of scientific investigation to the remaining cryopreserved embryos, whose state does not enable transference or cryopreservation, either having serious genetic anomalies or having been obtained without sperm fertilization. In this way, it outlined, among the research authorization criteria, a viability test which is close to that established by Brazilian norms.

One important ethical consensus in the legislations and regulations of the 25 countries is the recognition that frozen embryos remaining in assisted reproduction clinics can only be used in scientific research with the genitors' consent, an ethical guarantee also included in the Brazilian law. By similar ethical reference, a great number of legislations also prohibit embryo commercialization.

\section{Systems of ethical review of scientific research}

Almost all the countries with legislation recognize the need for embryonic stem cell research protocols to be reviewed by ethics committees. In the Brazilian case, this is foreseen by law, emphasizing an ethical review system that has existed for over ten years - the CEP/ Conep system. ${ }^{\text {a }}$ One peculiarity of this system is that it is directly linked to the Conselho Nacional de Saúde (National Health Council), an important health policy and social participation institution. There are almost 600 committees in all Brazilian regions, located in universities, research centers and hospitals.

Anvisa's Resolution $n^{\circ} 29$, from May $12^{\text {th }} 2008$, ${ }^{\text {b }}$ will promote the work of ethical review and embryonic stem cell research monitoring in Brazil, as it institutes procedures to register germinating tissue and cell banks, in addition to the human embryo information system in assisted reproduction clinics. The regulation of the Sistema Nacional de Embriões (SisEmbrio - National Embryo System) was an important step for the census of frozen embryos in reproductive clinics in Brazil. The only surveyed data currently available was produced by the Sociedade Brasileira de Reprodução Humana Assistida (SBRHA - Brazilian Society for Assisted Human Reproduction), in a sample comprised by the 15 major reproductive clinics, indicating the existence of 9,914 frozen embryos, of which 3,219 have existed for over three years. According to Anvisa, there are 104 centers affiliated to the SBRHA or to the Federação Brasileira das Sociedades de Ginecologia e Obstetrícia (Febrasgo - Brazilian Federation of Obstetrics and Gynecology Societies). ${ }^{c}$ The institutionalization of the SisEmbrio will enable monitoring of not only embryonic stem cell research, but also of the practice of reproductive medicine in Brazil.

\section{Beginning of life and embryonic stem cell research}

No countries were found to have faced the right to embryo research from the metaphysics of the beginning of life, as proposed by the ADIn. Almost all the countries that regulated embryonic stem cell research had to face the challenge of how to restrict scientific practice, and the majority chose to acknowledge the value of scientific freedom. The few countries that are regulated by religious values, such as the State of Israel, authorize embryonic stem cell research with a variety of possibilities. In the Islamic Republic of Iran, for example, embryonic stem cell research has been performed supported by favorable fatwas (religious edicts that authorize an action or not). The debate in the Islamic Republic of Iran began when the abortion law was changed, in 2003. ${ }^{11}$

Among the countries analyzed, the Italian Republic is the only one with technological development and scientific structure similar to the Brazilian one that criminalizes embryonic stem cell research. Its legislation on assisted reproduction, from 2004, was regulated by a decree from the ministry of health, in April 2008. The core of Italian law is to control access to reproductive technologies, significantly restricting new forms of family by introducing into the law the legal and symbolic recognition of the extracorporeal embryo as a person with rights. ${ }^{7}$ The Italian debate was morally intense and there are arguments, proposed by the ADIn, that are similar to the Italian law - in particular, the proposition that research with adult stem cells should be promoted, instead of embryonic stem cell research. One possible explanation for this peculiarity of the Italian law in the international perspective is the Catholic Church's participation in State decisions, where scientists were threatened with excommunication due to their defense of embryo research. ${ }^{12}$

\footnotetext{
a Conselho Nacional de Saúde. Resolução n 196, de 10 de outubro de 1996 [internet]. 1996. [cited 2008 May 24]. Available from: http://conselho.saude.gov.br/resolucoes /1996/Reso196.doc

${ }^{b}$ Agência Nacional de Vigilância Sanitária. Resolução n 29, de 12 de maio de 2008 [internet]. 2008. [cited 2008 May 24]. Available from:

http://e-legis.anvisa.gov.br/leisref/public/showAct.php?id=31098\&word=

c Agência Nacional de Vigilância Sanitária. GGSTO. Memorando nº77/2005. Brasília; 2005.
} 
The State of Israel is an interesting counterpoint to the Italian position. Differently from the Italian Republic or Brazil, the State of Israel is not a secular country and its political decisions are officially founded on religious values. It was in this country, where science, bioethics and religion met, that the issue of embryonic stem cell research had been under debate for almost a decade. After a moratorium request in 1999, the Bioethics Consulting Committee proposed to allow human embryo research in 2001, supported by two key arguments in the Jewish tradition: first, the moral status of a frozen embryo is similar to the gametes', thus not posing a threat to human dignity when manipulated for scientific purposes; second, scientific attempts to cure and treat diseases are highly valued. For this reason, the State of Israel is very supportive of genetic research, including therapeutic cloning. ${ }^{5,13}$

Latin America has a gap in its laws and regulations on embryonic stem cell research. Argentina is a country with potential for stem cell research in this area, but it does not have a law on this issue, and the normative act closest to the debate, Decree $\mathrm{n}^{\circ} 200$ from 1997, only prohibits human cloning research. In general terms, this political phenomenon could be attributed to this region's low technological potential to conduct medical research, except for Brazil; but it may also indicate the political and religious forces negotiating in these countries.

\section{CONCLUSIONS}

The tendency in international regulation is towards authorizing embryonic stem cell research. This type of research is allowed by 23 countries by a legal framework or ethical norms, among which only one restricts research to imported embryonic stem cell lines. In the universe of this study, the Italian Republic is the only country with technological capacity similar to the Brazilian one that prohibits embryonic stem cell research by law.

The most common regulations are the following: authorization of research with frozen embryos remaining from assisted reproduction clinics; prohibition of embryo commercialization and production for exclusive research purposes; requirement that research projects be assessed by ethics committees before they are performed; and mandatory consent from the couple who produced the embryo before its scientific use. All these ethical protections are guaranteed by Law $n^{\circ} 11,105 / 2005$.

In conclusion, the international tendency towards authorizing embryonic stem cell research must be understood not only as an investment in scientific progress by democratic States, but especially as an ethical affirmation of the relevant principle of freedom of research to promote knowledge as a public good. This position is emphasized by the expectation of therapeutic potentiality of embryonic stem cell research to treat and cure diseases without any medical care. 


\section{REFERENCES}

1. Bujuresten $K$, Hovatta O. Donation of embryos for stem cell research: how many couples consent? Hum Reprod. 2003;18(6):1353-5. DOI: 10.1093/humrep/ deg265

2. Burton P, Sanders K. Patient attitudes to donation of embryos for research in Western Australia. Med J Aust. 2004;180(11):559-61.

3. Deckers J. Why current UK legislation on embryo research is immoral: how the argument from lack of qualities and the argument from potentiality have been applied and why should be rejected. Bioethics. 2005;19(32):251-71. DOI: 10.1111/j.14678519.2005.00440.x

4. Devolder K. Human embryonic stem cell research: why the discarded distinction cannot be based on the potentiality argument. Bioethics. 2005;19(2):167-86. DOI: 10.1111/j.1467-8519.2005.00432.x

5. Gross ML, Ravitsky V. Israel: bioethics in a Jewish democratic state. Camb Q Healthc Ethics. 2003;12(3):247-55. DOI: 10.1017/ S0963180103123055

6. Guhr A, Kurtz A, Friedgen K, Löser P. Current state of human embryonic stem cell research: an overview of cell lines and their use in experimental work. Stem Cells. 2006;24(10):2187-91. DOI: 10.1634/ stemcells.2006-0053

7. Hanafin P. Gender citizenship and human reproduction in contemporary Italy. Fem Leg Stud. 2006;14(3):329452. DOI: 10.1007/s10691-006-9031-0
8. Heinemann T, Honnefelder L. Principles of ethical decision making regarding embryonic stem cells in Germany. Bioethics. 2002;16(6):530-42. DOI: 10.1111/1467-8519.00309

9. Hug K. Motivation to donate or not donate surplus embryos for stem cell research: literature review. Fertil Steril. 2008;89(9):263-77. DOI: 10.1016/j. fertnstert.2007.09.017

10. Jain T, Missmer AS. Support for embryonic stem cell research among infertility patients. Fertil Steril. 2008;90(3):506-12. DOI: 10.1016/j. fertnstert.2007.07.1311

11. Larijani B, Zahedi F. Health promotion, Islamic ethics and law in Iran. Daru. 2006;(Suppl 1):7-9.

12. Passoti J, Stafford N. It's legal: Italian researchers defend their work with embryonic stem cells. Nature. 2006;442(7100):229. DOI: 10.1038/442229a

13. Prainsack B. 'Negotiating life': the regulation of human cloning and embryonic stem cell research in Israel. Soc Stud Sci. 2006;36(2):173-205. DOI: $10.1177 / 0306312706053348$

14. Takala T, Häyry M. Benefiting from past wrongdoing, human embryonic stem cell lines, and the fragility of the German legal position. Bioethics. 2007;21(3):150-9. DOI: 10.1111/j.14678519.2007.00538.x

15. Warnock M. Report of the Committee of Inquiry into Human Fertilisation and Embriology. London: Department of Health and Social Security; 1984.

Research project funded by the Pan American Health Organization/World Health Organization in Brazil (Process $N^{\circ}$ : BR/ CNT/0801076). 


\section{ANNEX}

\section{LIST OF NORMATIVE ACTS}

\section{SOUTH AFRICA (research allowed)}

National Health Act. Act $n^{\circ} 61$ of 2003. Government Gazette, Cape Town, v. 469, n. 26595, 2004 July 23. Available from: <http://www.info.gov.za/view/ DownloadFileAction?id $=68039>$. Accessed on: 24 May 2008.

\section{GERMANY (importation allowed)}

Gesetzes zur Änderung des Stammzellgesetzes 6 fev. 2008. Drucksache 16/7981, Deutscher Bundestag, 16. Wahlperiode. Available from: $<$ http://www.biotechnologie.de/bio/ generator/Redaktion/PDF/de/2008-entwurfroespel, property $=$ pdf, bereich $=$, sprache $=e n, r w b=$ true . pdf $>$. Accessed on: 24 May 2008.

Gesetzes zur Sicherstellung des Embryonenschutzes im Zusammenhang mit Einfuhr und Verwendung menschlicher embryonaler Stammzellen (Stammzellgesetz - StZG). 27 fev. 2002. BGB1. I S. 2277, Drucksache 14/8394, Deutscher Bundestag, 14. Wahlperiode. Available from: <http://dip.bundestag. de/btd/14/083/1408394.pdf $>$. Accessed on: 24 May 2008.

\section{AUSTRALIA (research allowed)}

Prohibition of Human Cloning for Reproduction Act 2002. Act $\mathrm{n}^{\circ} 144$ of 2002 as amended. Compilation (current), Office of Legislative Drafting and Publishing, Attorney-General's Department, Canberra, 2007 June 12. Available from: <http://www.comlaw.gov.au/ ComLaw/Legislation/ActCompilation1.nsf/0/647EB C139FB39FDDCA2572F7007B272E/\$file/ProhibHumanCloningforRep2002_WD02.pdf $>$. Accessed on: 24 May 2008.

Research Involving Human Embryos Act 2002. Act $n^{\circ} 145$ of 2002 as amended. Compilation (current), Office of Legislative Drafting and Publishing, Attorney-General's Department, Canberra, 2007 June 12. Available from: < http://www.comlaw.gov.au/ComLaw/ Legislation/ActCompilation1.nsf/0/03F95E485D0423 1DCA2572F80003B1C3/\$file/ResearchInvolvingHumanEmbryosAct2002_WD02.pdf $>$. Accessed on: 24 May 2008.

\section{BRAZIL (research allowed)}

Agência Nacional de Vigilância Sanitária. Diretoria Colegiada. Resolução no 29, de 12 de May de 2008. Aprova o regulamento técnico para o cadastramento nacional dos bancos de células e tecidos germinativos (BCTG) e o envio da informação de produção de embriões humanos produzidos por fertilização in vitro e não utilizados no respectivo procedimento. Diário Oficial [da] República Federativa do Brasil, Brasília, DF, 13 May 2008. Available from: <http://e-legis.anvisa.gov. br/leisref/public/showAct.php?id=31098\&word=>. Accessed on: 24 May 2008.

Agência Nacional de Vigilância Sanitária. Diretoria Colegiada. Resolução n ${ }^{\circ}$ 33, de 17 de fevereiro de 2006. Aprova o regulamento técnico para o funcionamento dos bancos de células e tecidos germinativos. Diário Oficial [da] República Federativa do Brasil, Brasília, DF, 20 fev. 2006. Available from: <http://e-legis.anvisa.gov. br/leisref/public/showAct.php?id=20954\&word=\#'>. Accessed on: 24 May 2008.

Conselho Nacional de Saúde. Resolução no 196 , de 10 de outubro de 1996. Aprova as diretrizes e normas regulamentadoras de pesquisa envolvendo seres humanos. Diário Oficial [da] República Federativa do Brasil, Brasília, DF, n. 201, 16 out. 1996. Available from: <http://conselho.saude.gov.br/resolucoes /1996/ Reso196.doc $>$. Accessed on: 24 May 2008.

Lei $n^{\circ} 11.105$, de 24 de março de 2005. Regulamenta os incisos II, IV e V do $\S 1^{\circ}$ do art. 225 da Constituição Federal [...] e dá outras providências. Diário Oficial [da] República Federativa do Brasil, Brasília, DF, 28 mar. 2005. Available from: <http:/www.planalto.gov. br/ccivil_03/_Ato2004-2006/2005/Lei/L11105.htm>. Accessed on: 24 May 2008.

Presidência da República. Decreto $n^{\circ} 5.591$, de 22 de novembro de 2005. Regulamenta dispositivos da Lei $\mathrm{n}^{\circ} 11.105$, de 24 de março de 2005, que regulamenta os incisos II, IV e V do $\S 1^{\circ}$ do art. 225 da Constituição Federal, e dá outras providências. Diário Oficial [da] República Federativa do Brasil, Brasília, DF, 23 nov. 2005. Available from: <http://www.planalto.gov.br/ ccivil 03/ Ato2004-2006/2005/Decreto/D5591. htm>. Accessed on: 24 May 2008.

\section{CANADA (research allowed)}

Assisted human reproduction acts (2004, c. 2). Canada Gazette, chap. 2, c.6. Available from: $<$ http://canadagazette.gc.ca/partIII/2004/g3-02701.pdf >. Accessed on: 24 May 2008.

\section{CHINA (research allowed)}

人胚胎干细胞研究伦理指导原则, $24 \mathrm{dez} .2003$. Available from: <http://www.most.gov.cn/zfwj/ zfwj2003/200512/t20051214_54948.htm>. Accessed on: 24 May 2008.

\section{SINGAPORE (research allowed)}

Human Cloning and Other Prohibited Practices Act. 
Act $n^{\circ} 35$ of 2004. 1 Oct. 2004. Singapore Statutes, Attorney-General's Chamber \& Managing for Excellence Office, revised edition, Chapter 131B, 2005. Available from: <http://statutes.agc.gov.sg/non_version/cgi-bin/cgi_retrieve.pl?actno=REVED-131B\& doctitle $=$ HUMAN $\% 20$ CLONING $\% 20$ AND $\% 20$ OTHER \%20PROHIBITED\%20PRACTICES\%20A $\mathrm{CT} \% 0 \mathrm{a} \&$ date $=$ latest $\&$ method $=$ part $\& s \mathrm{l}=1>$. Accessed on: 24 May 2008.

\section{SOUTH KOREA (research allowed)}

Bioethics and safety act. Available from: $<$ http://www. moleg.go.kr/english/09/view.html?folder=_04_06_1 $\&$ code $=948773847149 . x m l>$. Accessed on: 24 May 2008.

\section{DENMARK (research allowed)}

Lov om ændring af lov om kunstig befrugtning $\mathrm{i}$ forbindelse med lægelig behandling, diagnostik og forskning m.v. (Forskning på embryonale stamceller). Lov nr 427 af 10 juni 2003, L 209. Available from: <https://www. retsinformation.dk/Forms/R0710. aspx?id=9734 $>$.Accessed on: 24 May 2008.

Lov om kunstig befrugtning i forbindelse med lægelig behandling, diagnostik og forskning m.v. Lov nr 460 af 10 juni 1997. Available from: <https://www.retsinformation.dk/Forms/R0710.aspx?id=84963>. Accessed on: 24 May 2008.

\section{SPAIN (research allowed)}

Ley 14/2007, de 3 de julio, de investigación biomedical. Boletín Oficial del Estado, Madrid, n. 159, 4 jul. 2007. Available from: $<$ http://www.congreso.es/constitucion/ ficheros /leyes_espa/1_014_2007.pdf $>$. Accessed on: 24 May 2008.

Ley 35/1988, de 22 de noviembre, sobre técnicas de reproducción asistida. Boletín Oficial del Estado, Madrid, n. 282, 24 nov. 1988. Available from: <http://www. congreso.es/constitucion/ficheros/leyes_espa/1_035_ 1988.pdf>. Accessed on: 24 May 2008.

\section{UNITED STATES OF AMERICA (research allowed)}

California (state). State Constitution. Art. XXXV. Available from: <http://www.leginfo.ca.gov/const-toc.html>. Accessed on: 24 May 2008.

Connecticut (state). Public Act n ${ }^{\circ}$ 05-149. An act permitting stem cell research and banning the cloning of human beings. 15 Jun. 2005. Available from: <http:// www.cga.ct.gov/2005/act/Pa/ 2005PA-00149-r00sb00934-pa.htm>. Accessed on: 24 May 2008.

Illinois (state). Executive Order creating the Illinois
Regenerative Institute for stem cell research, n. 6-2005. Executive Department, Springfield, IL. 2005 July 12. Available from: $<$ http://www.illinois.gov/ Gov/pdfdocs/ execorder2005-6.pdf>. Accessed on: 24 May 2008.

Maryland (state). Maryland Code. Article 83A. Title 5: Maryland Stem Cell Research Program. Available from: <http://www.michie.com/maryland/lpext.dll?f= templates \&fn $=$ main-h.htm\&2.0> . Accessed on: 24 May 2008.

Maryland (state). Maryland Stem Cell Research Act of 2006. Senate Bill 144. Available from: $<$ http://www.michie.com/maryland/lpext.dll?f= templates $\& \mathrm{fn}=$ main-h.htm\&2.0>. Accessed on: 24 May 2008.

\section{FINLAND (research allowed)}

Laki lääketieteellisestä tutkimuksesta. Laki 488/1999. 9 Apr. 1999. Available from: <http://www.finlex.fi/fi/laki/ alkup/ 1999/19990488>. Accessed on: 24 May 2008.

\section{FRANCE (research allowed)}

Loi n $2004-800$ du 6 août 2004 relative à la bioéthique. Journal Officiel de la République Française, Paris, texte 1 sur 92, 7 août 2004. Available from: <http://www. agence-biomedecine.fr/fr/doc/revision_loi060804. pdf $>$. Accessed on: 24 May 2008.

\section{NETHERLANDS (research allowed)}

Act Containing Rules Relating to the Use of Gametes and Embryos (Embryos Act). $1^{\circ}$ set. 2002. Official translation on Bulletin of Acts and Decrees [Staatsblad]. Available from: <http://www.minvws.nl/includes/dl / openbestand.asp?File=/images/eng-embryowettekst tcm 20-107819.pdf>. Accessed on: 24 May 2008.

\section{INDIA (research allowed)}

Department of Biotechnology. Indian Council of Medical Research. Guidelines for stem cell research and therapy. Nova Deli: Indian Council of Medical Research, 2007. Available from: <http://www.icmr. nic.in/stem cell/stem cell guidelines.pdf $>$. Accessed on: 24 May 2008.

\section{IRAN (research allowed)}

Iran Parliament. Therapeutic Abortion Act. Ref\#2/85876, 2005 June 21.

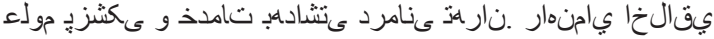
ي Available from: <http://mehr. tums.ac.ir/ShowCode.aspx?CodeID=5\&lang=fa $>$. Accessed on: 24 May 2008.

ISRAEL (research allowed) 
(היבר יאתב יטנג יונישו םדא טוביש) תיטנג תוברעתה רוסיא קוח

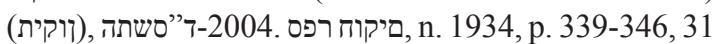
Mar. 2004. Available from: <http://www.knesset.gov. il/laws/heb/FileD.asp?Type=1\&LawNum=1934\&Sub Num=1>. Accessed on: 24 May 2008.

\section{ITALIA (research not allowed)}

Legge 19 febbraio 2004, n. 40. Norme in materia di procreazione medicalmente assistita. Gazzetta Ufficiale, n. 45, 24 febbr. 2004. Available from: <http://www. parlamento.it/parlam/ leggi/040401.htm>. Accessed on: 24 May 2008.

Ministero della Salute. Decreto 11 aprile 2008. Linee guida in materia di procreazione medicalmente assistita. Gazzetta Ufficiale, n. 101, 30 apr. 2008. Available from: <http://www.gazzettaufficiale.it/ guridb $/$ dispatcher? service $=1 \&$ datagu $=2008-04-30$ $\&$ task $=$ dettaglio \&numgu $=101 \&$ redaz $=08$ A02587 \& tmstp $=1209886579700>$. Accessed on: 24 May 2008.

\section{JAPAN (research allowed)}

Act on Regulation of Human Cloning Techniques. Act $\mathrm{n}^{\mathrm{o}} 146$ of 2000. 2001, June 6. Translation by 内閣官房. Available from: <http://www.cas.go.jp/ jp/seisaku/hourei/data/htc.pdf $>$. Accessed on: 24 May 2008.

\section{MEXICO (research allowed)}

Ley General de Salud. Available from: <http://www. diputados.gob.mx/LeyesBiblio/doc/142.doc>. Accessed on: 24 May 2008.

\section{NORWAY (research allowed)}

Lov om humanmedisinsk bruk av bioteknologi $\mathrm{mm}$ (bioteknologiloven). Lov-2003-12-05-100. Available from: <http://www.lovdata.no/all/nl-20031205-100. html $>$. Accessed on: 24 May 2008.

\section{PORTUGAL (research allowed)}

Conselho Nacional de Ética para as Ciências da Vida. Parecer sobre a investigação em células estaminais. Parecer $n^{\circ} 47$, de 11 de novembro de 2005. Available from: <http://www.cnecv.gov.pt/NR/rdonlyres/ FA945223-C04B-4B5D-A48C-E9F1864651D1/0/ P047_ParecerCE.pdf $>$. Accessed on: 24 May 2008.

REPÚBLICA DE PORTUGAL. Lei no 32/2006. Procriação medicamente assistida. Diário da Assembléia da República, I série, Nº.143/X/1, 26 jul. 2006. Avail- able from: <http://app.parlamento.pt/webutils/docs/ doc.pdf?path $=6148523063446 f 764 \mathrm{c} 3246795 \mathrm{a} 58687$ 74d546f334e7a67774c325276593342734c58526c65 48524263484a76646938794d4441324c3078664d7a4 a664d6a41774e6935775a47593d\&fich=L 322006. pdf\&Inline $=$ true $>$. Accessed on: 24 May 2008.

\section{UNITED KINGDOM (research allowed)}

Human Fertilisation and Embryology Act 1990. The UK Statute Law Database, Ministry of Justice, c. 37, 1990 Nov. 1. Available from: <http://www.statutelaw. gov.uk/legResults. aspx?LegType=All+Legislation\& Year $=1990 \&$ number $=37 \&$ searchEnacted $=0 \&$ exten t Match Only $=0 \&$ confersPower $=0 \&$ blanketAmendm ent $=0 \&$ TYPE $=$ QS \&NavFrom $=0 \&$ activeTextDocId $=$ $475578 \&$ PageNumber $=1 \&$ SortAlpha $=0>$. Accessed on: 24 May 2008.

\section{RUSSIAN FEDERATION (research allowed)}

Российская Федерация Федеральный закон от 20 мая 2002 г. N 54-Ф3 о временном запрете на клонирование человека. Available from: $<$ http://www. rg.ru/oficial/doc/federal_zak/54-fz.shtm>. Accessed on: 24 May 2008.

\section{SWEDEN(research allowed)}

Lag (1991:115) om åtgärder i forsknings- eller behandlingssyfte med ägg från människa. 14 Mar. 1991. SFS Databas t.o.m. SFS 2005:39. Available from: <http://62.95.69.15/cgi-bin/thw? $\$$ APPL $\}=$ SFST \& $\$$ BASE $\}=$ SFST \& $\{$ THWIDS $\}=.15 / 246$ $38 \& \$\{$ HTML $\}=$ sfst dok\& $\$$ TRIPSHOW $\}$ format $=$ THW\& $\$\{$ THWURLSAVE $\}=15 / 24638>$. Accessed on: 24 May 2008.

Lag (2003:460) om etikprövning av forskning som avser människor. 5 Jun. 2003. SFS Databas t.o.m. SFS 2008:192. Available from: <http://62.95.69.15/ c gi - b in/thw? \% $24 \% 7$ B H T M L \% 7 D=s fst $1 \mathrm{st} \& \% 24 \% 7$ B O O T M L $\% 7 \mathrm{D}=\mathrm{sfst}$ dok\& $\% 24 \% 7 \mathrm{BSNHT}$ ML\%7D=sfst_err\&\%24\%7 BBASE $\% 7 D=S F S T \& \% 24 \% 7 B T R I P$ SHOW\% 7D= format $\% 3 \mathrm{DTH} \mathrm{W} \& \mathrm{BET}=2003 \% 3 \mathrm{~A} 460 \% 24>$. Accessed on: 24 May 2008.

\section{SWISS CONFEDERATION (research allowed)}

Loi fédérale du 19 décembre 2003 relative à la recherche sur les cellules souches embryonnaires (Loi relative à la recherche sur les cellules souches, LRCS). Available from: <http://www.admin.ch/ch/f/rs/c810_31. html>. Accessed on: 24 May 2008. 


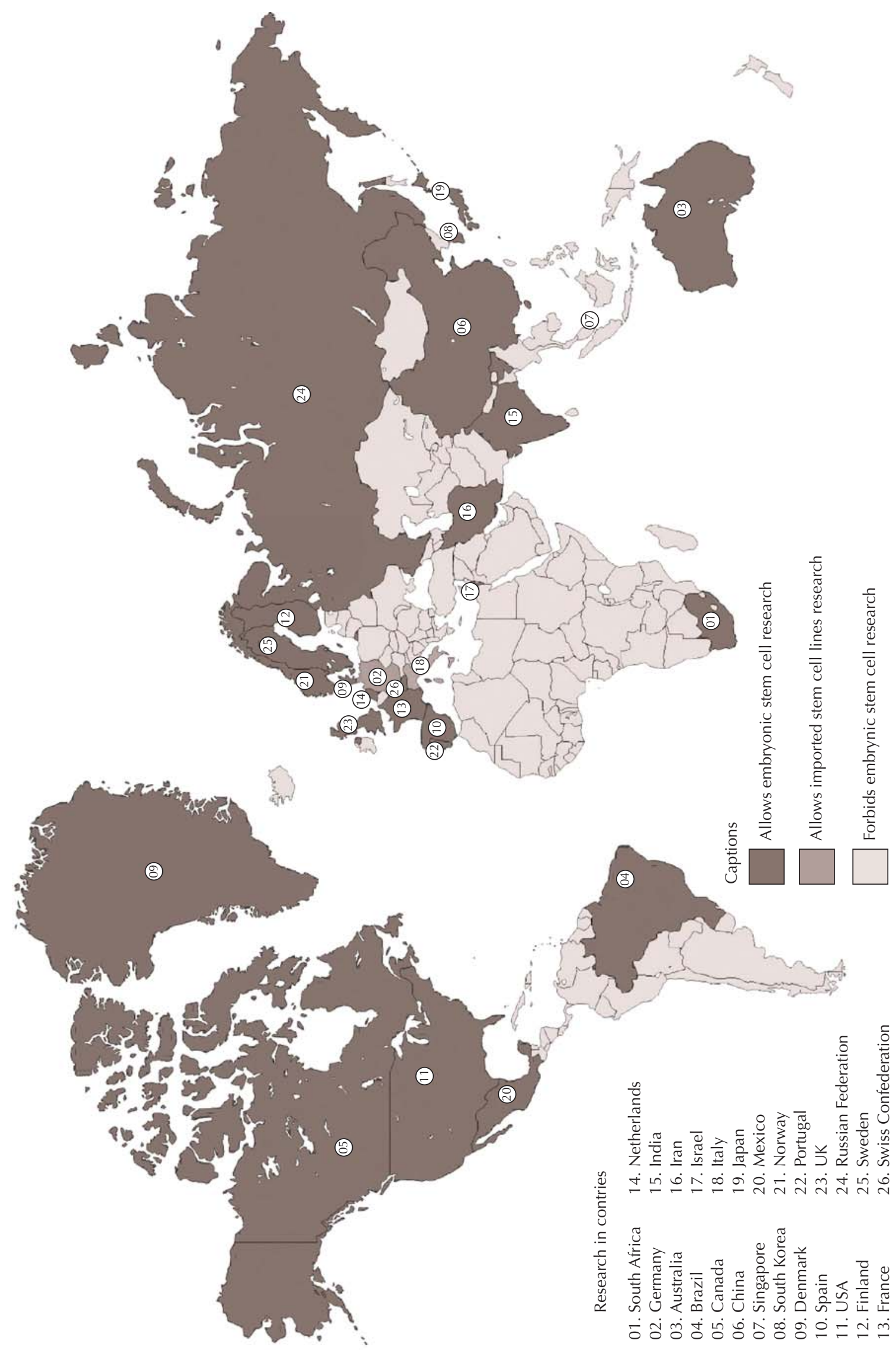

